\title{
A PÉNZÜGYI TERMÉKEK ÁRA
}

\author{
BANYÁR JÓZSEF
}

\begin{abstract}
Az ár fogalmát a pénzügyi termékekkel kapcsolatban általában nem használják, vagy ha igen, akkor össze-vissza. Néha azonosítják azt konkrét pénzügyi termékeknél, mint pl. a biztosításoknál és az opcióknál azok díjával, vagy úgy tekintenek rá, mint egy nem használt, „szabad” fogalomra, aminek ezért (szinte) tetszőleges értelmet lehet tulajdonítani. Ha jobban megvizsgáljuk azonban a dolgot, akkor arra jutunk, hogy igenis lehet egy, a többi termék és szolgáltatás árával konzisztens árfogalmat alkotni a pénzügyi „termékekre” is, a kulcs ehhez azonban annak felismerése, hogy ezek nem termékek, hanem standardizált szolgáltatáscsomagok. A dolog nehézsége az a sajátosság, hogy a szolgáltatás maga is arra az eszközre vonatkozik, amivel magát az árat mérjük, vagyis a pénzre. A szolgáltatótól pénz áramlik az ügyfél felé, az ügyféltől pénz áramlik a szolgáltató felé az összes pénzügyi szolgáltatásnál. Nem szabad árnak nevezni egyszerủen az egyik pénzáramot, viszont észre kell venni, hogy - várható értékben - az ügyféltől a szolgáltató felé irányuló pénzáram nagyobb, mint a fordított. A különbség - amit szoktak költségnek is nevezni - pont a szolgáltatás árának tekinthető, ha analógiának akármilyen javítási szolgáltatást veszünk. S ez az árfogalom konzisztens lesz, viszont nem magától értetődő, hogy hogyan kell azt reprezentálni. A probléma, hogy egy pénzügyi szolgáltatásnak - ellentétben a legtöbb, fizikai dologhoz kötött szolgáltatással - nincs magától értetődő egysége, illetve az, hogy sok olyan pénzügyi „,termék” van, aminek szolgáltatási periódusa akár évtizedekig is tarthat. Így speciális árreprezentáció kell, ami viszont épp megegyezik a pénzügyi termékek költségmutatóival, így az ár reprezentációjának kérdése visszavezethető a lehetséges költségmutatók problémájára.
\end{abstract}

\section{Bevezetés}

A dolgozat két, mostanában megjelent tanulmányom (az egyiket Vékás Péterrel közösen jegyzem) néhány fontos motívumával foglalkozik (Banyár [2015], BanyárVékás [2016]).

Ha kérdéssé fogalmazzuk át a címet, s arra keressük a választ, hogy mi is a pénzügyi termékek ára, akkor a válasz az első pillanatban egyértelmünek és egyszerünek tünik, mégpedig: 
- a hitelek ára a törlesztőrészlet,

- a biztosításoké a biztosítási díj,

- az opcióké az opciós díj stb.

Ugyanúgy, mint a zsemle vagy a szék ára, és ezzel a kérdést le is zárhatnánk.

\section{Bonyodalmak}

Sajnos azonban a probléma ennél bonyolultabb, hiszen ha a fenti hipotézisekből indulunk ki, akkor furcsa megállapításokra juthatunk. Ezek szerint ugyanis például a kamatmentes baráti kölcsön nem ingyenes. A fentiek alapján az csak akkor lenne az, ha egyáltalán nem kérnék vissza. Vagyis eszerint az ingyen hitel nem más, mint az ajándék pénz. Ez viszont nyilván nem így van, hiszen a kettőt nem kezeljük szinonimaként, és nagyonis jelentős különbséget érzünk a két dolog között. Az ajándékot nem kell visszaadni, a hitelt viszont igen, vagyis az inkább csak bérlés, tehát a hitelfelvétel pénzbérlés. A bérlés ára pedig a bérleti díj, vagyis a hitelkamat (és az esetleg egyéb fizetendő költségek). Tehát a hitelek ára mégsem az egész törlesztőrészlet, hanem csak a kamat (és még egyéb felszámított költségek - ha van ilyen).

De azért nem muszáj elsietnünk azt a megállapítást sem, hogy a pénzügyi termékek ára a kamat, mert abból viszont az következik, hogy a betételhelyezés mint pénzügyi "termék" nemcsak, hogy ingyenes banki szolgáltatás, hanem még nekem fizetnek kamatot - hiszen itt fordítva van, mint a hitelnél, én adom bérbe a pénzem a banknak kamatért. Ugyanez igaz a befektetési jegy vásárlására, ami így szintén ingyenes (sőt) pénzügyi szolgáltatás, hiszen lényegében ugyanolyan pénzbérbeadás, mint a betét.

Itt azonban a pénzügyi intézmény szolgáltatása az, hogy helyettünk adja bérbe a pénzünket, s a bérleti díj, vagyis a kamat egy részét elteszi. Olyasmi szolgáltatást végeznek itt nekünk, mint azok, akik nevünkben kiadják a lakásunkat, beszedik utána a bérleti díjat, ellenőrzik, hogy a bérlök fizetik-e a rezsit, stb., s ennek fejében levonnak valamit a nekünk járó bérleti díjból. Ha mi magunk intéznénk a bérbeadást, a bérleti díj, vagyis ezeknél a pénzügyi termékeknél a kamat, magasabb lenne, így a betét, befektetési jegy stb. ára valójában egyfajta feláldozott haszon, a lehetséges és a tényleges hozam különbsége.

Tehát úgy tünik, hogy a szék és a befektetési jegy ára mégsem ugyanaz. A befektetési jegy ára töredéke annak a pénznek, amennyiért megvásároltam azt, hiszen az erre költött pénzem kamatostul visszakapom (legalábbis általában ${ }^{1}$ ).

\footnotetext{
${ }^{1}$ Természetesen a pénzügyi szolgáltató, akire a pénzemet bíztam, csődbe mehet, vagy eleve kezelheti hütlenül is mások pénzét, így van valamekkora kockázata annak, hogy egyáltalán nem kapom vissza a pénzem. Ez egy érdekes probléma, de jól elkülöníthető attól, amit itt tárgyalok, ezért a továbbiakban ezzel nem foglalkozom.
} 
Amit nem kapok vissza, azért szolgáltatást végeztek, amit különben nekem kellett volna elvégezni. (Sőt, mivel ők ehhez jobban is értenek, mint én, ezt olcsóbban is végezték.)

Ha összehasonlítjuk az eddig vizsgált pénzügyi termékeket, vagyis a betételhelyezést, illetve a befektetési jegy vásárlását a hitelfelvétellel, akkor azt látjuk, hogy két osztályba sorolhatjuk őket.

E két osztály között a fö különbség az ügyfél és a pénzügyi szolgáltató helyzetében van. A hitel esetében elöször a szolgáltató fizet az ügyfélnek, aztán az a pénzügyi szolgáltatónak, a másik két esetben pedig ez fordítva történik, mintha a pénzügyi szolgáltató lenne a hitelfelvevő (valójában inkább egyfajta „hitelközvetítő"). A továbbiakban a vizsgálódásomat leszűkítem az ilyen jellegü pénzárammal bíró pénzügyi termékekre (annak ellenére, hogy a kiindulópontom a hitelfelvétel volt), de a megállapítások könnyen átfogalmazhatók a hiteltermékekre is.

\section{A pénzügyi termékek ára ${ }^{2}=\mathrm{A}$ szolgáltatás díja}

Amikor azt mondjuk, hogy pénzügyi „termék” ára, akkor nem fogalmazunk precízen, hiszen a háttérben nem termék, hanem szolgáltatás van. Ha a széknél maradunk, akkor a dolog nem annyira a szék vásárlásához hasonlít, hanem ahhoz, amikor a széket javításra adjuk be egy asztaloshoz. A javítás ára sem tartalmazza az egész szék árát! Ennek ellenére, a továbbiakban megtartjuk a „termék” szót, s nem helyettesítjük a bonyolultabb „standardizált szolgáltatáscsomag” kifejezéssel, hiszen ez a pontatlanság másfajta problémát nem okoz.

Tehát a befektetési jegy (UL, pénztár, betét stb.) ára a befektetett pénzem potenciális teljes hozama és a tényleges hozam különbsége.

Ha most bővítjük a vizsgált pénzügyi termékek körét, akkor első ránézésre azt mondhatnánk, hogy akkor ez az árdefiníció nem alkalmazható a neméletbiztosításokra. Hiszen ezeknél általában nem kapjuk vissza a pénzünket. Emiatt azt mondhatnánk, hogy a biztosítás csak akkor ingyenes, ha kárkifizetésként legalább annyit kapok, mint a fizetett díj - ha többet, akkor még jobb is, mint ingyenes. Igaz ez?

Nem igazán, hiszen ez csak az egyes biztosított nézőpontja. Az eddig vizsgált többi pénzügyi terméknél az egyes ügyfél és a szolgáltató nézőpontja egybeesett, de a nem-életbiztosítások esetében már nem. A biztosító nézőpontjából ugyanis azt mondhatjuk, hogy annak minden évben stabilan tervezhető díjbevétele és kárkifizetése van, ami nagyrészt egybeesik (az eltérés pont az, ami minket érdekel). Ugyanakkor, ha nem korlátozzuk le magunkat - a végső soron önkényesen megállapított - egy évre, hanem növeljük a vizsgált időtartamot, akkor azt mondhatjuk,

\footnotetext{
${ }^{2}$ A dolgozat nem foglalkozik a pénzügyi és biztosítási kockázatokkal, illetve azok ellenértékének a meghatározásával, azt adottnak veszi, jóllehet esetenként nagyon bonyolult ezek meghatározása. Ugyanakkor ez az „ellenérték” nem az „ár”, akkor sem, ha időnként úgy nevezzük. Az ár véleményem szerint - az, amit ebben a dolgozatban annak nevezek.
} 
hogy az minél hosszabb, annál stabilabb lesz az egyes biztosítottra jutó kárkifizetés is. Vagyis hosszabb távon már nem annyira szembeötlő a biztosító és az ügyfél nézőpontja közti különbség. Az eltérést az oldja fel, hogy a biztosítások esetében a szolgáltatásnál a várható szolgáltatást kell venni. Ez a többi eddig vizsgált pénzügyi termék esetében is igaz, csak ott a várható szolgáltatás és a tényleges közti eltérés szinte nulla, a biztosításban viszont nagyon nagy is lehet. A biztosításban amúgy a várható szolgáltatás nem más, mint

- előzetesen: a nettó díj,

- utólag: a tényleges kárhányad.

Vagyis a biztosítás ára is hasonlóképpen származtatható, mint az előbb vizsgált többié, csak némileg másképp kell azt megfogalmazni, valahogy így: az ügyfél által befizetett díjak + az elérhető (teljes) hozam - a várható kárkifizetés (= nettó díj).

Tehát a pénzügyi termékek ára általánosabban nem más, mint

az ügyfél várható, a pénzügyi szolgáltatónak tett befizetései + az azokon elérhető (teljes) hozam - a pénzügyi szolgáltatótól az ügyfél felé irányuló várható kifizetések.

Egyszerübben megfogva a dolgot:

a pénzügyi termékek ára = a szolgáltató ügyfél felé felszámolt költségei.

Ezt a megfogalmazást pedig már minden további nélkül tudjuk alkalmazni az életbiztosításokra is. Ezek - jellegüket tekintve - a betétek, illetve befektetési jegyek és a nem életbiztosítások kombinációi. Mindkettőtől elsősorban abban különböznek, hogy jellemzően hosszú tartamú szerződések, amelyek egyfajta technikai bonyodalmat okoznak a rövid tartamú termékekhez képest, amikor az ár konkrét megkonstruálásáról van szó.

Ha azt gondolnánk, hogy a biztosítás ára a biztosítási díj stb., ugyanúgy, mint a széknél, akkor azt is gondolhatnánk, hogy az ügyfél már mindent tud, ami őt érdekli, s nem szükséges számára információt adni arról, hogy mennyi a nettó díj - illetve ennek komplementere: a biztosítás költségrésze. Hiszen a bútorboltban sincs feltüntetve a szék ára mellett, hogy ebből mennyi a fa, a kárpit stb. része. De ha ezt a felfogást elvetjük, s magunkévá tesszük a fentieket, akkor hirtelen teljesen legitimmé válik a biztosítás költségrészének nyilvánosságra hozatala, hiszen végső soron ez lesz számára az árinformáció. Ugyanez a helyzet minden más pénzügyi termék esetében is, vagyis az ügyfél jogosan kíváncsi azok költségeire, hiszen az az ár. S az is jogos kívánsága, hogy ne széttöredezett árinformációk tömegét kapja, hanem egyetlen mutatóban összefoglalt tömör információt. Azt is mondhatjuk ezért, hogy az ár a pénzügyi terméknél nem más, mint egy költségmutató. A kérdés ezért, hogy ezt hogyan lehet, illetve célszerü megkonstruálni? 


\section{Az ár mint költségmutató megkonstruálása}

A költségmutató megkonstruálását - terjedelmi okokból - a fent említett pénzügyi termékek közül leszükítjük kettőre: a befektetési jegyekre és az életbiztosításokra. A hitelekről fent már beszéltem. A betétek esetében - amelyek költségeinek logikája hasonló a befektetési jegyekhez - az a technikai probléma, hogy elsődlegesen nem a költség mint információ áll rendelkezésünkre, hanem az ügyfélnek fizetendő kamat, s ebből kell előbb magát a költséget a költségmutatóhoz előállítani. A nem életbiztosításokra vonatkozó költségmutató pedig már könnyen előállítható a nála egyszerűbb befektetési jegy, illetve a nála bonyolultabb életbiztosítás példáján. Érdemes még megjegyezni, hogy a befektetési jegyekre és az életbiztosításokra (de nem a betétekre és a nem életbiztosításokra) jelenleg egy közös európai költségmutató fejlesztése folyik. Az e mutató által érintett pénzügyi termékeket összefoglalóan "packaged retail insurance and investment products"-nak, röviden PRIIPs-nek nevezik. (A munka állásáról ld. ESMA, EBA, EIOPA [2015]. Jelen anyag nem követi ennek a dokumentumnak a gondolatmenetét és megoldásait.)

\section{Költségmutató rövid tartamú termékekre}

A befektetési jegyre vonatkozó költségmutató megkonstruálásakor kihasználhatjuk azt, hogy ez egy relatíve egyszerü termék, határozatlan tartammal (ami a gyakorlatban általában rövid távot jelent), amit nyugodtan vehetünk egy évnek, és ahol a felszámított költségek jól ismertek.

Ha bevezetjük a következő jelöléseket, akkor a rövid (1 éves) tartamú, egyszeri befizetésre szóló befektetési jegyre vonatkozó költségmutató egyszerű lesz:

$$
\frac{C}{G P},
$$

(= „bruttó díjas változat”) vagy

$$
\frac{C}{P}
$$

ahol

GP: az ügyfél bruttó befizetése,

P: az ügyfél nettó befizetése = GP-C (költségek nélkül),

$\mathrm{C}=$ GP-P: a szolgáltató költsége.

A második képlet (= a „nettó díjas változat”) hozzávetőlegesen megegyezik az EU-ban néhány éve az ezekre a termékekre bevezetett "total expense ratio" (=TER) mutatóval.

Ezt a mutatót (mindkét változatát) kétféleképpen interpretálhatjuk: 
1. mint kamatveszteséget (hozamrést), illetve

2. mint költséghányadot.

Igazából ez csak a hosszú tartamú termékekre vonatkozó költségmutatóból visszatekintve látszik, ugyanis a kétféle interpretáció 1 éves tartamnál egybeesik. A több évesnél viszont már nem, ott fontos világosan látni, hogy melyik interpretáció szerint képezzük meg a költségmutatót.

\section{Költségmutató hosszú tartamú termékekre}

A kamatveszteség-mutató (mégpedig a nettó díjas változat) egy lehetséges általánosítása több évre és rendszeres éves befizetésekre, rögzített $i$ hozammal, az alábbi egyenlet megoldása $r$-re:

$$
\sum_{j=0}^{n-1}\left(G P_{j}-C_{j}\right) \cdot\left(\frac{1}{1+r}\right)^{j}=\left(\frac{1}{1+r}\right)^{n} \cdot \sum_{j=1}^{n} G P_{j}
$$

Ez leginkább egy hosszú ( $n$ éves) tartamú, rendszeres díjas befektetési alapra vonatkozó költségmutató. Ilyen általában nincs, de az életbiztosítók által értékesített „befektetési egységekhez kötött” (BEK) életbiztosítások ehhez nagyon hasonlóak, azzal az eltéréssel, hogy ott a „költség” egy része egy haláleseti életbiztosítás díja lesz, vagyis igazából nem költség. Ha mégis annak tekintjük, akkor kaphatunk ezekre a konkrét életbiztosításokra egy nem tökéletes, de kielégítő költségmutatót. Pontosan így járt el 2009-ben a Magyar Biztosítók Szövetsége (MABISZ [2009]), amelyik erre a speciális életbiztosításra „teljes költségmutató” (TKM) névvel bevezetett egy ilyen mutatót.

Ezt némiképpen lehet tovább általánosítani, ha feltesszük, hogy van egy garantált éves $i$ hozam:

$$
\sum_{j=0}^{n-1}\left(G P_{j}-C_{j}\right) \cdot\left(\frac{1}{1+r}\right)^{j}=\left(\frac{1}{1+r}\right)^{n} \cdot \sum_{j=1}^{n} G P_{j} \cdot(1+i)^{n-j}
$$

Ekkor a költségmutató nem $r$, hanem $r-i$ lesz (a MABISZ TKM speciális, $i=0 \%$-os garantált hozamot feltételez). Az is látható, hogy a MABISZ-mutató megoldása $n=1$-re: $\mathbf{r}=\frac{C}{G P-C}$ lesz, ami nagyjából a TER-nek megfelelő mutató. Hosszabb tartamokra már egyre kompromisszumosabban tudjuk ezt az egyezőséget megkapni. Például $n=2$-re (de egyetlen befizetésre): $r \approx \frac{\frac{C}{2}}{G P-C}$ lesz.

Ez a mutató azonban túl egyszerű ahhoz, hogy az összes életbiztosításra ki lehessen terjeszteni. A BEK-biztosítások többsége esetében a haláleseti szolgáltatás, és így annak a díja is elenyésző, emiatt nem okoz túl nagy problémát, ha azt - 
amúgy helytelenül - költségnek tekintjük. Az úgynevezett hagyományos életbiztosításoknál azonban ez már nagy probléma, így célszerübb, ha itt áttérünk a bruttó díjas alváltozatra. Ennek egy elég általános képlete az alábbi:

$$
\begin{gathered}
\sum_{j=0}^{n-1}{ }_{j \mid} p_{x} \cdot G P_{j} \cdot\left(\frac{1}{1+r}\right)^{j}= \\
=\sum_{j=0}^{n-1}{ }_{j \mid} p_{x} \cdot A B_{j} \cdot\left(\frac{1}{1+r}\right)^{j}+\sum_{j=0}^{n-1}{ }_{j \mid} q_{x} \cdot D B_{j} \cdot\left(\frac{1}{1+r}\right)^{j+1}+{ }_{n \mid} p_{x} \cdot M B_{n},
\end{gathered}
$$

ahol $p$ a túlélési, $q$ a halálozási valószínüség ( $x$ éves belépési korú biztosítottra, $j$ éves „halasztással”), AB, DB és MB a járadék-, haláleseti- és elérési szolgáltatás.

A költségmutató itt: $i-r$ lesz, ahol $i$ a garantált hozam, ami a képletben nem jelenik meg külön, hanem tudjuk, hogy a biztosító által ígért AB, DB és MB szolgáltatások kalkulálása során már „beszámították” azt.

A két változat különbsége, hogy az előző, nettó díjas változat esetében a tartalékra, itt viszont a teljes befizetett díjra vetítjük a kamatveszteséget.

Ez tehát a kamatveszteség/hozamrés típusú költségmutató. De hogyan néz ki hosszabb tartamra a költséghányad típusú változat (amit - ugyanúgy, mint a hozamrés típusút - vetíthetünk nettó és bruttó díjra egyaránt)? A bruttó díjra vetített költséghányad típusú költségmutató képlete:

$$
\begin{gathered}
(1-c) \cdot \sum_{j=0}^{n-1}\left(j \mid p_{x} \cdot G P_{j} \cdot\left(\frac{1}{1+i}\right)^{j}=\right. \\
=\sum_{j=0}^{n-1}\left(j \mid p_{x} \cdot A B_{j} \cdot\left(\frac{1}{1+i}\right)^{j}+\sum_{j=0}^{n-1}\left(j \mid q_{x} \cdot D B_{j} \cdot\left(\frac{1}{1+i}\right)^{j+1}+\right.\right. \\
+{ }_{(n \mid} p_{x} \cdot M B_{n} \cdot\left(\frac{1}{1+i}\right)^{n},
\end{gathered}
$$

ahol a költségmutató - vagyis az ár: $c$.

Fontos különbség a hozamrés típusú mutatóhoz képest, hogy itt $r$ helyett $i$ („beépített hozam” = „technikai kamatláb”) szerepel.

\section{7. Összefüggés a költséghányad és a hozamrés típusú mutatók között}

A költséghányad és a hozamrés típusú mutató kölcsönösen megfeleltethető egymásnak. A kettő közti összefüggést az alábbi ábrák mutatják: 


\section{A költséghányadok hozamréssé transzformált értéke a tartam függvényében}

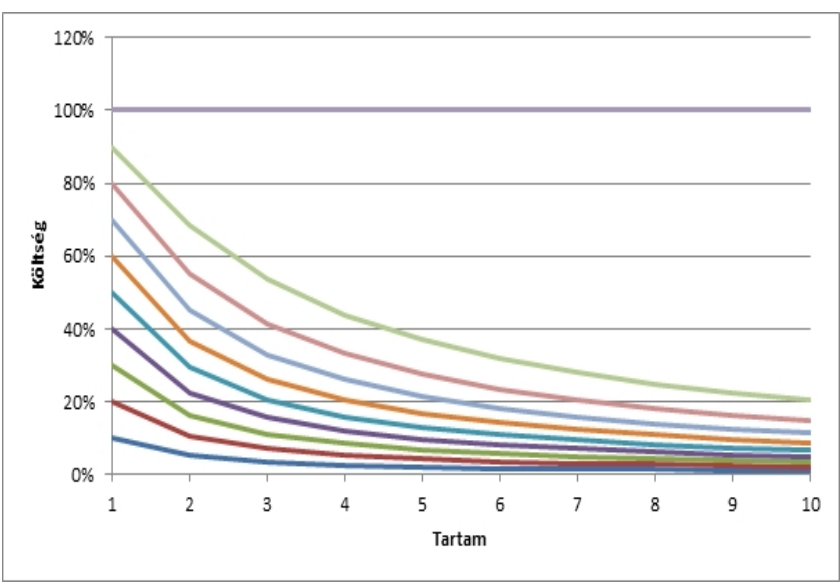

1. ábra. $10 \%, 20 \%, \ldots, 90 \%, 100 \%$ költséghányadokat transzformáltunk át hozamréssé. Egyéves tartamnál a kettő egybeesik, de a tartam növekedésével egyre kisebb lesz az ugyanahhoz a költséghányadhoz tartozó hozamrés.

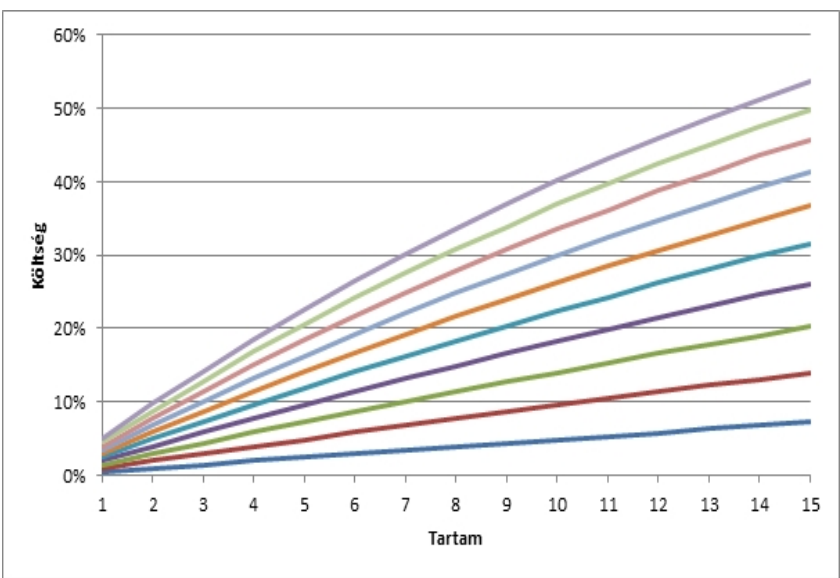

2. ábra. Ez a fordított transzformációt mutatja, vagyis itt a kamatrést transzformáljuk költségrésszé. Látható, hogy a $0,5 \%, 1 \%, \ldots, 4,5 \%, 5 \%$ nagyságú kamatrések a tartam növekedésével egyre nagyobb költségrészeknek felelnek meg. 


\section{Hivatkozások}

[1] Banyár JózSEF: Általános költségmutató(k) pénzügyi termékekre, Szigma, Vol. XLVI No. 3-4, pp. 187-217 (2015).

[2] BANYÁr JózSef - VÉKÁs PÉTer: A pénzügyi termékek ára, Közgazdasági Szemle, Vol. LXIII, április, pp. 380-406 (2016).

[3] ESMA, EBA, EIOPA [2015]: Joint Consultation Paper PRIIPs Key Information Documents - https://eiopa.europa.eu/Pages/Consultations/ EBA-EIOPA-and-ESMAConsultation-Paper-on-the-PRIIPs-Key-Information-Documents.aspx - Letöltés: 2016. július 25 .

[4] MABISZ [2009]: TKM mutató - http://www.mabisz.hu/hu/tkm.html - Letöltés: 2016. július 25 .

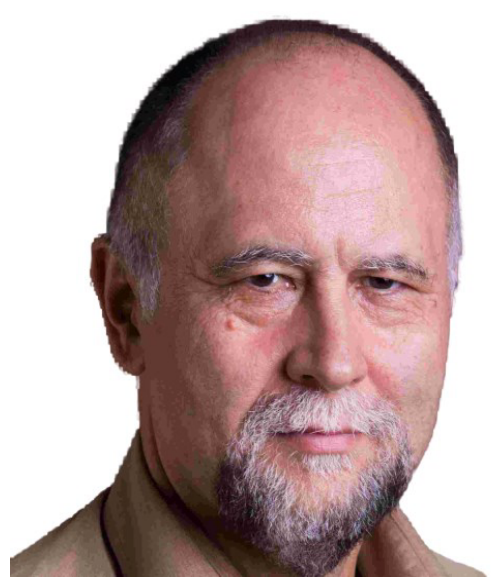

Banyár József 1961-ben született. Habilitált egyetemi docens, a Budapesti Corvinus Egyetem Operációkutatás és Aktuáriustudományok Tanszékének oktatója. PhD-jét 2011-ben a BCE-n szerezte (értekezése címe: A kötelező öregségi járadékok lehetséges modelljei), ugyanitt habilitált 2017-ben. A BCE elődjénél, a Marx Károly Közgazdaságtudományi Egyetemen végzett 1985-ben matematikus közgazdász szakon, s ugyanitt (akkor BKÁE) szerezett 2000-ben aktuáriusi diplomát is. A BCE-nél (illetve elődjeinél) 1985 óta dolgozik matematika, politikai gazdaságtan, mikroökonómia tanszékeken, illetve a Biztosítási Oktató és Kutató Csoportnál. Dolgozott aktuáriusként és vezetőként biztosítónál, illetve a pénzügyi felügyeletnél az elnök biztosítási- és nyugdíjtanácsadójaként. Több könyve, illetve tankönyve jelent meg angol és magyar nyelven, az MTMT-ben jelenleg több mint 100 publikációja található. Fő kutatási területe jelenleg: nyugdíjelmélet, pénzügyi fogyasztóvédelem.

\section{BANYÁR JÓZSEF}

Budapesti Corvinus Egyetem 1093 Budapest, Fővám tér 8. jbanyar@uni-corvinus.hu 


\section{THE PRICE OF FINANCIAL PRODUCTS}

\section{JÓZSEF BANYÁR}

The concept of "price" in connection with financial product is generally not used, or if still, indiscriminately. Sometimes it refers to the premium of some financial products as insurances and options, or it is regarding as a "free", underused concept, which can be used in almost any, arbitrary meaning. But, if we examine the matter more detailed, we could concluded, that it is possible to create a price concept also for financial "products" which is consistent with the price of other products or services. The key to this is to recognize, that these are not "products" but standardized service bundles. The topic's main difficulty is that specialty that the (financial) service itself refers to the same tool with which the price itself is measured: the money. At all financial services money flows from the provider towards the client and vice versa. It is not allowed simply to call as price one of these flows (from the client towards the provider), but it have to recognized, that - in expected value - the flow from the client is larger than the opposite. The difference - which can be called as cost - is just the price, if we use as analogy any repair service. Another problem, that financial service - contrary to the most other services linked to physical object - has not obvious unit, and that there are many financial "products", whose service period can last even decades. So we need a special price representation, which in turn just equal to the cost indicators of the financial products, so the problem of the representation of the price can be originated in the problem of possible cost indicators.

Keywords: cost indicators, price

Mathematics Subject Classification (2000): 62P05, 91B24 